\title{
NEMATODES ASSOCIATED WITH SUGARCANE IN THE DOMINICAN REPUBLIC
}

Sugarcane is the most important agricultural crop in the Dominican Republic. In most countries where sugarcane is cultivated, different plantparasitic nematode species, or those suspected of being plant-parasitic, have been found in association with the crop. The report of Liu, et al. ${ }^{2}$, is apparently the sole published record pertaining to nematodes associated with sugarcane in the Dominican Republic. This report is, however, limited to the nematodes found in the area of the Central Romana in the southeastern part of the country. The purpose of the investigations reported herein was to survey those areas where information related to nematodes associated with sugarcane was not available. The areas investigated were: south-central part (Duquesa-Yacó, Yacó-Guanuma, Santa Fé, Consuelo, Catarey), southwestern part (Barahona) and north-central part (Montellano and Esperanza). Samples consisting of $300 \mathrm{cc}$ of soil and $25 \mathrm{~g}$ of roots were collected from the different localities. The nematodes from the soil samples were extracted using the sieving, decanting, Baermann-Funnel method. Root samples were macerated in a blender for $15 \mathrm{~s}$ and then processed in the same manner as the soil.

The nematode species identified, and their presence in the different localities surveyed, are presented in order of their importance in table 1 . The observations conducted indicated a marked deterioration of the sugarcane root system. Most of this deterioration probably was caused by species of the genus Pratylenchus, mainly $P$. zeae, as evidenced by the close association found between this nematode species and deteriorated roots, as well as by its presence in all the samples taken from the different localities surveyed. Very rarely were roots observed to be free of lesions or of discolored tissue.

The root-knot nematode, Meloidogyne incognita, although isolated from all the localities sampled, was found more closely associated with light soils. The incidence of this nematode in the sandy soils of Ingenio Montellano in the north-central part of the country was so high that the ratoon cane was markedly stunted, wilted and chlorotic. The germination of new cane also was severely affected. The roots of these plants were heavily galled and poorly developed.

Two species of Tylenchorhynchus ( $T$. curvus and $T$. crassicaudatus) were found in association with stunted and chlorotic cane having stubby and dis-

1 Manuscript submitted to Editorial Board October 1, 1974.

2 Liu, Lii-Jang, Ellis, T. O., and Arcenaux, G., Diseases of sugar-cane and their control at Central Romana, Proc. 12th ISSCT (Puerto Rico, 1965), Elsevier Publ. Co., Amsterdam, pp. 1226-1231, 1967. 
TABLE 1.-Presence of known and suspected plant-parasitic nematodes associated with sugarcane in eight Dominican Republic localities

\begin{tabular}{|c|c|c|c|c|c|c|c|c|}
\hline \multirow[b]{2}{*}{ Nematode } & \multicolumn{8}{|c|}{ Locality } \\
\hline & $\begin{array}{l}\text { Du- } \\
\text { quesa } \\
\text { Yaco }\end{array}$ & $\begin{array}{l}\text { Yac6 } \\
\text { Gua- } \\
\text { numa }\end{array}$ & $\underset{\text { Santa }}{\text { Sé }}$ & $\begin{array}{c}\text { Con- } \\
\text { suelo }\end{array}$ & Catarey & $\begin{array}{c}\text { Bara- } \\
\text { hona }\end{array}$ & $\begin{array}{c}\text { Monte- } \\
\text { llano }\end{array}$ & $\begin{array}{l}\text { Espe- } \\
\text { ranza }\end{array}$ \\
\hline Pratylenchus sp. & & & & $\mathbf{x}$ & & $\mathbf{x}$ & & \\
\hline P. zeae & $\mathbf{x}$ & $\mathbf{x}$ & $\mathrm{x}$ & $\mathbf{x}$ & $\mathbf{x}$ & $\mathbf{x}$ & $\mathbf{x}$ & $\mathbf{x}$ \\
\hline$P$. crenatus & $\mathbf{x}$ & & & $\mathbf{x}$ & $x$ & $\mathbf{x}$ & & \\
\hline P. brachyurus & & $\mathbf{x}$ & & & & & & \\
\hline P. scribneri & & & & & & $\mathbf{x}$ & & \\
\hline Meloidogyne incognita & $\mathrm{x}$ & $\mathbf{x}$ & $\mathrm{x}$ & $\mathbf{x}$ & $\mathbf{x}$ & $\mathbf{x}$ & $\mathbf{x}$ & $\mathbf{x}$ \\
\hline Tylenchorhynchus curvus & $\mathbf{x}$ & $\mathbf{x}$ & $\mathbf{x}$ & $\mathbf{x}$ & & $\mathbf{x}$ & $\mathbf{x}$ & $\mathbf{x}$ \\
\hline T. crassicaudatus & & & & & $\mathbf{x}$ & & $\mathbf{x}$ & \\
\hline Helicotylenchus spp. & $\mathbf{x}$ & $\mathrm{x}$ & $\mathbf{x}$ & $\mathbf{x}$ & $\mathbf{x}$ & $\mathrm{x}$ & $\mathrm{x}$ & $\mathbf{x}$ \\
\hline H. dihystera & $\mathbf{x}$ & $\mathbf{x}$ & $\mathbf{x}$ & $\mathbf{x}$ & $\mathbf{x}$ & $\mathbf{x}$ & $\mathbf{x}$ & $\mathbf{x}$ \\
\hline H. curvatus & & & & $\mathbf{x}$ & $\mathbf{x}$ & $\mathbf{x}$ & $\mathbf{x}$ & \\
\hline H. flatus & & $\mathbf{x}$ & $\mathbf{x}$ & $\mathbf{x}$ & & & & \\
\hline H. retusus & & & & $\mathbf{x}$ & $\mathbf{x}$ & $\mathbf{x}$ & $\mathbf{x}$ & \\
\hline H. tropicus & & & $\mathbf{x}$ & $\mathbf{x}$ & $\mathbf{x}$ & & & \\
\hline H. microcephalus & & & & & & $\mathbf{x}$ & $\mathbf{x}$ & \\
\hline$H$. concavus & & & & & & & $\mathbf{x}$ & \\
\hline H. truncatus & & & & & & $\mathbf{x}$ & & \\
\hline Rotylenchulus parvus & & & & & & $\mathbf{x}$ & $\mathbf{x}$ & $\mathbf{x}$ \\
\hline Criconemoides spp. & $\mathbf{x}$ & $\mathbf{x}$ & & $\mathbf{x}$ & $\mathbf{x}$ & $\mathbf{x}$ & $\mathbf{x}$ & $\mathbf{x}$ \\
\hline Paratylenchus & & & & & & $\mathbf{x}$ & & $\mathbf{x}$ \\
\hline Hemicycliophora penetrans & & & $\mathbf{x}$ & & & & & \\
\hline Ditylenchus spp. & & $\mathbf{x}$ & $\mathbf{x}$ & $\mathbf{x}$ & $\mathbf{x}$ & $\mathbf{x}$ & & \\
\hline Tylenchus spp. & $\mathbf{x}$ & $\mathbf{x}$ & $\mathbf{x}$ & $\mathbf{x}$ & $\mathbf{x}$ & $\mathrm{x}$ & $\mathbf{x}$ & \\
\hline Aglenchus costatus & & $\mathbf{x}$ & & & $\mathbf{x}$ & & & \\
\hline Boleodoroides clavicaudatus & $\mathbf{x}$ & & & & & & & \\
\hline Xiphinema americanum & & & & & $\mathbf{x}$ & $\mathbf{x}$ & $\mathbf{x}$ & $\mathbf{x}$ \\
\hline Longidorus spp. & & $\mathbf{x}$ & & & & $\mathbf{x}$ & $\mathbf{x}$ & \\
\hline Trichodorus spp. & & & & & $\mathbf{x}$ & $\mathbf{x}$ & $\mathbf{x}$ & $\mathbf{x}$ \\
\hline Aphelenchoides spp. & & & $\mathbf{x}$ & & $\mathbf{x}$ & & & \\
\hline
\end{tabular}

torted roots. $T$. curvus was encountered more frequently than $T$. crassicaudalus.

Eight species of Helicotylenchus were identified, with $\boldsymbol{H}$. dihystera predominant. Helicotylenchus was associated with roots consistently having few root hairs.

Rotylenchulus parvus was found only in the southwestern part at Barahona and in north-central Montellano and Esperanza. This nematode species was associated with roots exhibiting severe distortion and occasional lesions.

No specific symptoms could be corroborated with other nematode 
species found but as many of them are known to be parasitic on various plant species it seems reasonable to suspect that some were feeding on cane roots.

On the basis of available information it seems that the sugarcane-nematode situation in the Dominican Republic is very similar to that of Puerto Rico with the exception that $R$. parvus has not been as yet ${ }^{3}$ isolated from cane fields in Puerto Rico.
J. Roman
Department of Entomology
L. Grullón
Centro de Investigaciones Agropecuarias
San Crist6bal, República Dominicana

${ }^{2}$ Román, Jessé, Nematode problems of sugarcane in Puerto Rico, Tropical Nematology, Univ. of Florida Press, ed. by G. Smart and V. Perry, pp. 61-67, 1968. 